\title{
Dance Recital for the Men of the American Legion in April
}

52 Let's say they came in pairs: two dancing girls, two mothers, two old men posted by the door. Say the men shared a stack of silver dollars to be pressed later into the palms of the girls. There were others of course - a hundred more dancers and a decorated audience that clapped on cue, not letting on that the little girls were no substitute for the forms of entertainment overseas.

Onstage the Knapp sisters monkey-rolled for the patient crowd, while out back the two mothers lipsticked their daughters' cheeks and pinned corsages to their chests.

As for the girls, they did not like each other much. They tapdanced together for the sakes of their mothers and everyone else, but at school they played apart. Still, they were the best the outof-town dancing teacher had to offer. No one, it seemed-not the girls nor their mothers nor the audience-liked the out-of-town teacher, who was surly and fat, though none of that is of any real consequence here. Yet, if not for her, then who would have taught the little girls to dance?

One girl wore a yellow costume, the other red, and their hair fell shining down their backs. Together they resembled small plump birds. Their turn was coming soon. They were still except for rocking on the part of the yellow-costumed girl, who had to pee.

"Hold still, you," said her mother.

"It's nerves. They'll be great."

"The batons were terrible."

"They'll be wonderful."

"Couldn't catch a thing."

If you studied the cheeks and brows of the daughters you could see what the mothers had been. The mother of the yellow-suited girl kept stealing glances to make sure her daughter was the prettier. But both girls were extravagantly the same.

The mother of the yellow girl would go home and slap her son, who had skipped the recital altogether. She would smoke late, alone on the porch, before finally going in to bed. The mother of the red girl would go to bed early, but she would get up after 
everyone was asleep and leave the house. She would walk steadily to a cabin outside town, where she would lie with a man who was not her husband. I cannot be with you, she would tell him, and he would nod, yes. By dawn she would be home, pulling breakfast things from the refrigerator.

At the recital, there was a pair of husbands too. They were in the front row, an open seat beside each like a buffer or a pause. When finally the out-of-town teacher struck up the chords to "Sewanee River" and the little girls tapped onto the stage, the men sat up expectantly. Then the mothers slid in beside them. The father of the red-costumed girl pressed his wife's hand and thought, This.

Not everyone was paying attention, but if you were you saw that the girls danced backwards! The yellow-costumed girl led off in the wrong direction and the other one followed. You caught plenty of their sequined behinds but little of their fronts. It wasn't so bad. Their corsages winked. Their heads shone. The tapping sounded just the same, and from the middle of the hall it was hard to notice anything wrong.

The mothers noticed. The fathers did too, but mostly they felt the mothers beside them, and the father of the red-costumed girl held his wife's hand that much tighter.

A year from now some things would be different. The mother of the red-costumed girl would come home early one morning to find her husband waiting at the kitchen table. Why, he would ask, and she would not know the answer. Soon she would leave, taking their daughter with her. After that, the girls would no longer tapdance together. This, at least, would provide some small relief to the girls themselves.

When the music ended, the little girls curtseyed toward the wall. The audience clapped and the mothers stood, each with an eye on her child. The out-of-town teacher did not turn from the piano. Outside, the river moaned and cracked. The ice would go out that night.

Later, the little girls - sweatered now but still in taps-headed for the door. They collected their coins from the two men and slipped out, each a dollar richer. 